\title{
Stereotipasi Peran Gender Wanita dalam Program Televisi Anak di Indonesia
}

\author{
Sunarto \\ Program Magister Ilmu Komunikasi - Program Pascasarjana Universitas Diponegoro \\ Jl. Imam Bardjo, SH No. 5 Semarang; 024-8446986; \\ HP. 08156503458/e-mail: sunartoo@yahoo.com
}

\begin{abstract}
The background of this study was an increasing of actual and symbolical violence on women. Describing personal and structural violence on women in children's television program such as Ronaldowati, Si Pitung The Master, Ben7 and Baim Anak Sholeh were the objective of this study. To Analysing the phenomena it was used gender structuration theory as a derivative of political economic media approach on critical paradigm. The theory tried to explain the process of production and reproduction a gender relation in society through optimizing the rules and resources that occupied by male and female actors in social interaction. Actors negotiated their schema interpretatives, norms and facilities in the interaction. In the negotiation, male actors had social positon more superior than female actors. The effect of the situation created an asymmetrical gender relation in society. Male actors defeated female actors in every social institutions. Media was one of the institution where the superiority of male actors glorified. Female actors could not empower theirs structure to overcome male's structure in the media industies. A critical discourse analysis was applied to frame this study. The result showed there was structural violence on women in gender stereotypization. It was recommended to produce programmes that describing gender role fairly.
\end{abstract}

\begin{abstract}
Abstrak
Latar belakang penelitian ini adalah peningkatan kekerasan aktual dan simbolis pada wanita. Tujuan penelitian ini menggambarkan kekerasan personal dan struktural pada perempuan dalam program televisi anak-anak seperti Ronaldowati, Jagoan Si Pitung, Ben7 dan BaimAnak Sholeh. Teori strukturasi gender sebagai turunan dari pendekatan media politik ekonomi pada paradigma kritis digunakan untuk menganalisis fenomena ini. Teori tersebut mencoba menjelaskan proses produksi dan reproduksi hubungan gender dalam masyarakat melalui optimalisasi aturan dan sumber daya yang diduduki oleh aktor laki-laki dan perempuan dalam interaksi sosial. Aktor dinegosiasikan dalam skema interpretatif, yang melibatkan interaksi aturan dan berbagai fasilitas yang ada . Dalam negosiasi, aktor laki-laki memiliki posisi sosial yang lebih unggul dari aktor perempuan. Pengaruh situasi tersebut menciptakan sebuah relasi gender asimetris dalam masyarakat.Aktor laki-laki mengalahkan aktor perempuan dalam setiap lembaga-lembaga sosial. Media adalah salah satu lembaga dimana keunggulan aktor laki-laki dimuliakan.Aktor perempuan tidak bisa memberdayakan posisi mereka untuk mengatasi struktur laki-laki dalam industri media. Analisis wacana kritis telah diterapkan untuk membingkai studi ini. Hasil penelitian menunjukkan adanya kekerasan struktural pada perempuan terkait stereotip gender. Tulisan ini direkomendasikan untuk menghasilkan program yang menggambarkan peran gender secara berimbang.
\end{abstract}

Kata kunci: Stereotipisasi, Kekerasan Struktural 


\section{Pendahuluan}

Penelitian ini berada dalam lingkup bahasan komunikasi massa, khususnya terkait dengan persoalan efek isi kekerasan media televisi terhadap penonton anak-anak, utamanya isi kekerasan struktural terhadap kaum wanita dalam program anak. Latar belakang penelitian adalah adanya kekerasan aktual terhadap wanita yang merebak dimana-mana (Soetrisno, 1999; Davies, 1994; Ribka, 1998). Di Indonesia, kekerasan terhadap wanita cenderung meningkat dengan tajam. Menurut laporanKomisi Nasional (Komnas) Perempuan pada tahun 2001 terdapat 3.169 kasus meningkat menjadi 20.391 kasus di tahun 2005. Pada tahun 2009 terjadi 143.586 kasus kekerasan. Angka ini meningkat 263 persen dari tahun 2008 yang terjadi 54.425 kasus kekerasan. Pola kekerasan yang cukup menonjol adalah kekerasan psikologis dan seksual di ranah keluarga/ relasi personal, komunitas dan negara (Kompas, 9 Januari 2002:7; Kompas, 8 Maret 2010:12).

Selain kekerasan aktual, kekerasan simbolikal juga ada dimana-mana. Beberapa kajian terhadap media massa umum di luar Indonesia dan di Indonesia menunjukkan, isi media (koran, majalah, media elektronik, lagu, film atau sinetron, iklan, dan kemasan audio-visual musik) banyak menampilkan peran sosial limitatif untuk kaum wanita (Bemmelen, 1992; Ibrahim dan Suranto, 1998; Wolf, 1997; Gupta dan Jain, 1998: 34; Siew dan Kim, 1996: 75; Steeves, 1993: 39-41; Soemandoyo, 1999: 257; Komnas Perempuan, 2002: 155-170; Idrus, 2004: 31-42). Gambaran kekerasan terhadap wanita tersebut juga dijumpai pada program tayangan televisi anak produksi lokal. Data tindak kekerasan terhadap kaum wanita melalui program anak lokal relatif belum banyak dilakukan (Guntarto, 2000; Sendjaja, 2003). Diduga isi media televisi untuk anak produksi lokal juga merepresentasikan kekerasan tertentu terhadap kaum wanita. Terlebih apabila mencermati Gerbner (2003) yang menyatakan, violence on television is an integral part of a system of global marketing.

Permasalahan yang muncul terkait apa saja macam ekspresi kekerasan terhadap wanita yang muncul dalam program anak produksi lokal? Apa ideologi gender dominan di balik tindak kekerasan tersebut?

Tujuan penelitian untuk mendeskripsikan kekerasan terhadap wanita dalam program televisi anak-anak produksi lokal beserta ideologi dominan di balik kekerasan tersebut. Manfaat akademis terkait dengan pengembangan Teori Strukturasi Gender sebagai alat analisis untuk menjelaskan proses produksi dan reproduksi relasi gender dalam konteks kajian komunikasi massa. Manfaat praktis untuk memberi masukan pengelola program anak untuk bisa menghasilkan tayangan berkualitas dan sehat bagi pertumbuhan mental anak. Manfaat sosial bisa digunakan untuk mendorong masyarakat melek media (media literation) terhadap isi televisi yang punya potensi pengaruh negatif terhadap perkembangan ideologis anak terkait relasi gender.

Upaya menjawab persoalan digunakan teori strukturasi gender sebagai salah satu varian teori ekonomi-politik media dalam paradigma kritis. Secara singkat teori strukturasi gender mencoba menjelaskan proses produksi dan reproduksi relasi gender dengan menggunakan secara maksimal aturan (rules) dan sumber daya (resources) yang dimiliki aktor pria dan wanita dalam interaksi sosial. Dalam struktur gender, interaksi aktor pria dan aktor wanita melibatkan penggunaan kekerasan simbolik dan non simbolik sebagai modalitas yang melekat dalam seksualitas mereka. Dominasi gender terjadi ketika aktor pria mempunyai kecenderungan besar menggunakan kekerasan sebagai mekanisme penundukan terhadap aktor wanita (Golding \& Murdock, 1991; 1995; Giddens, 1986a; Giddens, 1986b; Wolffensperger, 1991; Mosco, 1996; Guba \& Lincoln, 1994; Neuman, 1997).

Penelitian ini mengasumsikan adanya kekerasan personal dan struktural tertentu terhadap wanita dalam program anak produksi lokal. Kekerasan ini hadir karena struktur industri televisi masih didominasi ideologi patriarki dan kapitalisme.

\section{Metode Penelitian}

Penelitian bertipe deskriptif ini menggunakan pendekatan kualitatif dalam paradigma 
kritis dengan menggunakan analisis wacana kritis (critical discourse analysis) Fairclough (1985) sebagai metoda penelitian.

Objek penelitian berupa program televisi anak produksi lokal semacam serial Ronaldowati, Si Pitung The Master, Ben7, dan Baim Anak Sholeh yang ditayangkan periode Agustus - September 2009 yang diperoleh dari rekaman Komisi Penyiaran Pusat (KPI) Pusat. Data diperoleh dengan cara melibatkan beberapa coder mahasiswa tingkat sarjana Program Studi Ilmu Komunikasi Universitas Diponegoro Semarang.

Analisis data dalam analisis wacana kritis mempunyai dua tahapan analisis: (1) analisis peristiwa komunikasi (communicative events); dan (2) analisis tatanan wacana (order of discourse).

Dalam analisis peristiwa komunikasi (communicative events) dilakukan analisis teks (text), analisis praktek wacana (discourse practice), dan analisis praktek sosio-budaya (socio-cultural practice). Analisis teks dilakukan dengan menggunakan analisis isi kuantitatif untuk menemukan kekerasan personal dan analisis isi kualitatif dengan analisis naratif Greimas untuk menemukan kekerasan struktural. Analisis praktek wacana dilakukan dengan metoda wawancara mendalam terhadap pengelola program televisi yang menjadi objek penelitian. Analisis praktek wacana dilakukan dengan analisis dokumen relevan (undang-undang, peraturan, kepustakaan, dan lain-lain). Analisis tatanan wacana (order of discourse) dilakukan melalui analisis linguistika terkait analisis genre dan wacana.

Keabsahan data (goodness criteria) penelitian dalam paradigma kritis ini dibingkai dalam konteks historis (historical situatedness) perkembangan kapitalisme dalam industri televisi di Indonesia.

Hasil penelitian yang dilaporkan dalam bentuk artikel ini merupakan hasil penelitian tahap pertama terkait analisis teks. Analisis praktik wacana dan analisis praktik sosio-budaya belum dilakukan karena merupakan tahap penelitian berikutnya.

\section{Hasil Penelitian dan Pembahasan}

Hasil penelitian analisis teks secara kuantitatif menemukan adanya kekerasan personal terhadap tokoh wanita oleh tokoh pria. Kekerasan personal adalah kekerasan yang dilakukan oleh aktor kasat mata. Dalam kasus ini kekerasan oleh aktor pria terhadap wanita. Secara umum, dalam berbagai film yang diteliti, baik tokoh pria maupun tokoh wanita sama-sama terlibat sebagai pelaku tindak kekerasan tertentu terhadap tokoh yang lain, baik tokoh pria maupun tokoh wanita. Secara khusus, kekerasan personal yang dilakukan tokoh pria terhadap tokoh wanita oleh tokoh pria terjadi dalam bentuk kekerasan psikologis (Ronaldowati oleh Reno; Siti oleh Ben), fisik dan psikologis (Audi dan Ling-ling oleh Monster Karang).

Hasil penelitian analisis isi kualitatif dengan analisis naratif menemukan adanya kekerasan struktural terhadap tokoh wanita oleh struktur atau sistem sosial tertentu. Dimaksudkan dengan kekerasan struktural adalah kekerasan terhadap aktor wanita oleh aktor yang tidak kasat mata (tidak terlihat) berupa sistem atau nilai-nilai tertentu yang hidup di masyarakat. Dalam penelitian ini kekerasan struktural terjadi dalam bentuk: (1) dominasi pria atas wanita (Ronaldowati: Tweety Diculik; Si Pitung The Master: Pasukan Belalang Tempur \& Monster Karang; Ben7: Pesumo Pembuat Onar \& Mencari Buah Naga) dan (2) stereotipisasi wanita (Baim Anak Sholeh: Bang Rafi Kaya; Si Pitung The Master: Pasukan Belalang Tempur; Ronaldowati: Pertandingan Sepakbola).

Dominasi terjadi ketika secara kuantitatif maupun kualitatif keberadaan tokoh pria lebih dominan dibanding tokoh wanita. Secara kuantitatif ditunjukkan melalui besaran jumlah satu kelompok lebih banyak dibanding kelompok yang lain. Secara kualitatif dominasi dipahami sebagai kekuasaan oleh satu kelompok atas kelompok yang lain. Dalam Ronaldowati hal itu terlihat dari banyaknya tokoh pria yang terlibat (empat orang) dibanding tokoh wanita (dua orang) dalam lingkaran pertemanan Ronaldowati. Secara kualitatif, dominasi terjadi melalui banyaknya inisiatif yang berasal dari tokoh pria untuk mengatasi persoalan yang muncul. Dalam kasus "Penculikan Tweety" tokoh Ceking lebih banyak inisiatif untuk mem-bebaskan Tweety dibanding Ronaldowati. Padahal Ronaldowati adalah tokoh utama yang namanya menjadi judul film. 
Dalam Si Pitung dominasi tokoh pria secara kuantitatif juga sangat kentara. Hal itu ditunjukkan melalui kehadiran Pitung, Bebe, Peter, Daus, Bang Rozak. Tokoh wanita hanya ada dua orang yaitu Lingling dan Audi serta Reni dan Kemuning yang muncul bergantian. Secara kualitatif dominasi terjadi dalam bentuk tindakan si Pitung mengatasi berbagai masalah yang muncul. Dalam hal ini dominasi si Pitung melawan Anak Super, Monster Belalang maupun Monster Karang. Tokoh wanita hanya menjadi korban yang harus diselamatkan.

Dalam Baim Anak Sholeh secara kuantitatif ada empat orang anak laki-laki dan dua orang anak perempuan dalam relasi persahabatan Baim dan kawan-kawannya. Secara kualitatif, dominasi terjadi ketika Baim digambarkan lebih sering punya inisiatif dibanding teman-temannya yang lain. Teman-teman Baim lebih banyak menjadi pengikut saja (followers).

Dalam Ben 7 tokoh pria yang sering muncul adalah Ben dan Bang Tama. Sedang tokoh wanita hanya Siti saja. Dominasi secara kualitatif ditunjukkan melalui tindakan Ben bertarung mengatasi pegulat sumo dan tokoh-tokoh jahat lain. Dalam pertarungan tersebut hanya Ben saja yang bertindak secara aktif. Sedang tokoh lain hanya memberi dukungan saja. Bahkan yang lebih parah, pertarungan tersebut malah dijadikan tontonan. Meski demikian, dalam hal tertentu, peran Siti dengan kemampuan gaibnya kadang menyelamatkan Ben darikekalahan dengan musuh-musuh mereka. Hal itu terjadi dalam episode "Mencari Buah Naga".

Meskipun secara keseluruhan lebih banyak ditemui dominasi tokoh pria dibanding tokoh wanita, misalnya peran besar Pak Ustad untuk menentukan benar atau salah atas suatu tindakan tertentu (dalam Baim Anak Sholeh), dalam beberapa hal juga ditunjukkan peran besar wanita atas tokoh pria. Hal itu, misalnya saja, ditunjukkan melalui peran dominan Mama Baim atas Papa Baim. Papa Baim cenderung menjadi suami yang takut sama istrinya.

Stereotipe dipahami sebagai keyakinan di mana pria mempunyai sifat-sifat tertentu dan harus melakukan hal-hal tertentu dan wanita mempunyai sifat-sifat yang lain dan harus melakukan hal-hal tertentu yang lain. Dalam masyarakat stereotipi ini penting karena digunakan sebagai basis sikap dan perilaku anggota masyarakat satu sama lain. Stereotipi peran-gender ini dilanggengkan melalui mekanisme komunikasi antar pribadi dan dilekatkan dalam struktur masyarakat melalui institusi-institusi semacam keluarga, agama, sistem pendidikan, sistem ekonomi, dan sistem politik.

Labeling stereotipisasi menjadi bias ketika keberadaan wanita digambarkan sebagai penguasa ranah domestik yang berlaku semenamena terhadap suaminya atau kaum pria. Sebagaimana ditunjukkan oleh Mama Baim yang bersikap dan berlaku sebagai ibu rumah tangga dominan atas suaminya. Mama Baim mengatur dengan ketat apa yang boleh dan tidak boleh dikerjakan oleh suaminya. Bahkan, secara pleonastik, Mama Baim mengklaim Baim hanya adalah anak mama, bukan anak papa, semata-mata karena Mama telah mengandung selama 9 bulan dan selalu membawa bayi Baim kemana-mana. Mama adalah sumber kebenaran. Papa sumber persoalan dan masalah. Peran semacam ini menjadikan stereotipi yang semula wajar dan normal menjadi berlebihan dan cenderung menyudutkan peran sosial yang dilakukan wanita. Situasi semacam ini dalam skala lain juga ditunjukkan oleh tokoh Siti yang “menguasai” Ben. Bagaimana Siti memaksa Ben untuk terus berlatih semata-mata agar mampu mengalahkan para pesumo yang mengacau kampung. Tidak jarang karena kesal Ben mengumpat Siti dengan sebutan "bawel". Sebaliknya Siti menyebut Ben sebagai jagoan "cemen" ketika kalah bertarung dengan para pesumo. Stereotipisasi yang lain juga ditemui dalam Pitung The Master yang menggambarkan keberadaan tokoh wanitanya hanya sebagai korban kejahatan tokoh antagonis dengan tugas utama berteriak-teriak ketakutan. Dalam Ronaldowati stereotipisasi terjadi ketika tokoh Ronaldowati digambarkan sebagai sosok yang pasif, pengalah dan penghindar konflik.

\section{Peran Gender}

Dalam pandangan Richmond-Abbott (1992: 3-15), peran-gender (gender-role) sering dikacaukan dengan peran-jenis kelamin (sexrole). Keduanya jelas mempunyai makna berbeda. 
Peran seks merupakan perilaku yang ditentukan oleh jenis kelamin biologis, misalnya menstruasi untuk wanita dan ereksi untuk pria, serta ejakulasi untuk kedua seks. Sementara perangender merupakan ekspektasi pada perilaku maskulin dan feminin yang keseluruhannya diciptakan secara sosial. Ekspekstasi-ekspektasi ini digagas dan dilanggengkan melalui lembaga-lembaga dan nilai-nilai dari satu masyarakat tertentu. Dalam ekspektasi ini, misalnya saja, melahirkan dan menyusui dikaitkan dengan peran-seks feminin, tetapi membesarkan anak merupakan sebuah perangender. Orang yang membesarkan anak-anak dan segala sesuatu terkait dengan hal itu ditentukan oleh sebuah budaya tertentu dan struktur kekuasaan dalam budaya tersebut. Berbagai ketidakadilan di masyarakat terkait peran-gender bisa saja diubah melalui sosialisasi jikalau sumber ketidakadilan kultural yang ada di masyarakat juga turut diubah. Misalnya bisa saja kaum wanita diajarkan untuk berorientasi pada prestasi dan kompetisi jikalau mereka tidak dijauhkan dari dunia olahraga, akademik, ataupun pekerjaan-pekerjaan lain yang dinilai berharga. Kaum pria juga bisa diajari nilainilai pengasuhan dan ekspresi emosi jikalau masyarakat berhenti untuk menghukum kaum pria dengan nilai-nilai semacam itu.

Faktor kekuasaan mempunyai peran penting dalam menentukan relasi gender yang berlangsung. Dengan adanya faktor kekuasaan ini bisa menjelaskan terjadinya stratifikasi perangender yang memberikan kekuasaan lebih pada kaum pria dan bagaimana definisi maskulin dan feminin secara historis selalu direproduksi. Dengan perkataan lain, karena kaum pria mempunyai kekuasaan dan mendominasi berbagai institusi sosial yang ada, sifat-sifat dan pekerjaan-pekerjaan maskulin lebih dihargai dan maskulinitas menjadi sebuah koleksi sifat-sifat yang mengarahkan pada keberhasilan di masyarakat. Jika kaum pria disosialisasikan untuk menjadi maskulin, mereka akan mempunyai sifat-sifat mandiri (independence), agresif (aggresiveness), dan kompetitif (competitiveness) yang akan membuat mereka berhasil dan tetap menjaga kaum pria dalam posisi kekuasaan. Jika kaum wanita disosialisaskan untuk menjadi feminin dengan sifat pasif (pasiveness) dan tergantung (dependent), maka akan sulit buat mereka untuk mendapakan kekuasaan dan mengubah struktur nilai-nilai dan lembaga-lembaga yang ada.

Meskipun terdapat perbedaan isi sesuai konteks budayanya, peran-gender biasanya berisi karakteristik-karateristik yang umum. Karakteristik tersebut meliputi ekspektasi pada sifat-sifat personal (personal traits) tertentu (wanita mengasuh dan tergantung, pria asertif dan mandiri), peran-peran sosial (social roles) (pria sebagai ayah dan pencari nafkah keluarga, wanita sebagai istri dan ibu), dan pekerjaan-pekerjaan atau posisiposisi sosial (social positions) (pria menjadi tentara dan politisi, wanita menjadi jururawat dan relawan).

Gender sering dilekatkan dengan peranperan sosial dan posisi-posisi sosial semacam itu dengan cara-cara berbeda menurut konteks waktu dan masyarakat tertentu. Di AS awal, posisi sebagai sekretaris dan jururawat dikerjakan kaum pria. Pada budaya lain, posisi sebagai suami bisa saja menjadi bagian dari peran-gender feminin, misalnya saja pada masyarakat Dahomean di Afrika. Di Amerika Serikat (AS) sekarang ini, kaum wanita diperimbangkan lebih baik mengerjakan pekerjaan semacam guru SD dan pekerja sosial karena pekerjaan ini membutuhkan sifat pengasuhan dan kepekaan tertentu yang diasosiasikan dengan femininitas. Kaum pria dipertimbangkan lebih baik menjadi ahli mesin dan dokter karena mereka dilekatkan dengan sifat yang lebih logis dan rasional. Di Cina, kebanyakan ahli mesin adalah wanita dan mereka dinilai lebih baik mengerjakan pekerjaan itu dibanding kaum pria. Di Soviet, kebanyakan dokter dan dokter gigi adalah kaum wanita.

\section{Stereotipe Peran Gender Wanita}

Istilah stereotip (stereotype), sebagaimana dijelaskan Unger dan Crawford (1992:107), digunakan pertama kali oleh Walter Lippman untuk menggambarkan satu jenis perilaku manusia. Menurut Lippman, stereotipe utamanya secara kultural menentukan gambaran-gambaran yang mengganggu antara bagian-bagian kognitif individu dan persepsinya tentang dunia. Stereotip sampai sekarang dipahami sebagai sebuah proses yang mendistorsi realita. Selanjutnya oleh Unger dan Crawford dijelaskan, stereotipi terjadi ketika 
individu-individu dikelompokkan oleh individuindividu lain sebagai mempunyai sesuatu yang sama karena mereka anggota dari sebuah kelompok tertentu atau kategori orang tertentu.

Sementara itu Giddens (1992: 247) menjelaskan pikiran stereotipi (stereotypical thinking) dalam kaitannya dengan prasangka ( $p r e j u-$ dice). Menurut Giddens, semua pikiran melibatkan kategori-kategori yang digunakan manusia untuk mengelompokkan pengalamannya. Kadang kategori tersebut kaku dan menyakitkan. Misalnya, sebutan "hitam" dan "Yahudi" berkonotasi negatif karena didasarkan pada informasi tertentu yang ditafsirkan sesuai konteks penafsir. Demikian halnya dengan sebutan “Indon" untuk orang Indonesia yang ada di Malaysia. Pikiran stereotipi bisa tidak menyakitkan ketika isi emosinya bersifat "netral" dan jauh dari kepentingan individu. Misalnya saja orang dari dunia Timur punya pandangan stereotipe tertentu pada orang Barat (bebas, seks bebas, dan lain-lain), tetapi hal itu hanya punya sedikit konsekuensi pada kebanyakan orangorang tersebut. Meski kita punya pikiran stereotip, kita tidak benci kepada orang-orang dari Barat. Kita sambut kedatangan mereka sebagai wisatawan penting. Akan tetapi, ketika stereotipi dikaitkan dengan kecemasan atau ketakutan, persoalannya menjadi lain. Stereotipi dalam kondisi tersebut biasanya membantu pembentukan sikap penuh prasangka atau kebencian kepada kelompok yang sedang dipersoalkan. Orang kulit putih, misalnya, percaya bahwa semua orang kulit hitam pemalas dan bodoh. Dengan menggunakan keyakinan semacamitu, orang kulit putih lalu merendahkan orang kulit hitam. Di Amerika sekarang ini, belum semua orang kulit putih mau menerima Barack Obama sebagai presiden mereka.

Sama seperti stereotipe lain, stereotipe gender (gender stereotypes) menurut Unger dan Crawford (1992: 107 - 109), mempunyai karakteristik: (1) kelompok yang menjadi sasaran stereotipe biasanya mudah dikenali dan relatif tidak mempunyai kekuasaan; (2) terdapat sedikit persetujuan antara gabungan gambaran dari kelompok itu dengan karakteristik aktual dari anggota kelompok itu; (3) mispersepsi yang muncul merupakan hasil dari beberapa bentuk bias dalam mekanisme prosesing-informasi; (4) mispersepsi ini sulit untuk diubah, meskipun orang yang mempunyai keyakinan stereotipe ini telah menemui sejumlah contoh yang tidak mengkonfirmasikannya; (5) stereotipe mengimplikasikan perbandingan nyata antara kelompok dengan kerugian dari kelompok yang distereotipekan; (6) orang-orang tidak sadar bahwa mereka mempunyai pandangan stereotipe dan akan menolak bahwa mereka menggeneralisasikan individuindividu; (7) stereotipe dicirikan oleh relatif sedikit variabilitas diantara individu-individu dengan karakteristik yang mereka nilai sesuai dengan kelompok yang dipertanyakan.

Menurut Richmond-Abbott (1992), masyarakat mempunyai ekspektasi-ekspektasi kultural tertentu yang dilekatkan pada sikap dan perilaku pria dan wanita. Faktor biologis jenis kelamin (maleness atau femaleness) digunakan untuk mengkonstruksi sebuah kategori sosial dari gender (masculinity atau femininity). Ekspektasiekspektasi kultural yang dikaitkan dengan gender sering diekspresikan sebagai stereotipi peran-gender (gender-role stereotypes). Dalam hal ini, stereotipe merupakan deskripsi yang sangat disederhanakan dari sekelompok orang. Dengan demikian stereotipe peran-gender mengandung arti keyakinan-keyakinan dimana pria mempunyai sifat-sifat tertentu dan harus melakukan hal-hal tertentu dan wanita mempunyai sifat-sifat yang lain dan harus melakukan hal-hal tertentu yang lain. Dalam masyarakat stereotipe ini penting karena digunakan sebagai basis sikap dan perilaku anggota masyarakat satu sama lain. Stereotipe perangender ini dilanggengkan melalui mekanisme komunikasi antar pribadi dan dilekatkan dalam struktur masyarakat melalui institusi-institusi semacam keluarga, agama, sistem pendidikan, sistem ekonomi, dan sistem politik.

Deaux dan kawan-kawan (dalam Unger dan Crawford, 1992: 112) menunjukkan perbedaan atribut yang dilekatkan pada beberapa konsep: (1) wanita (menarik, feminin, cerdas, sensitif, emosional) dan pria (kuat, menyembunyikan perasaan, bertindak macho, sexy, berotot); (2) ibu rumah tangga (membersihkan benda-benda, memasak, menjaga anak-anak, keibuan, sibuk) dan pekerja kasar pria (pabrik, pekerja keras, klas menengah-bawah, tidak berpendidikan, anggota serikat pekerja); (3) olah-ragawati (berotot, bentuk tubuh bagus, kuat, agresif, berotot) dan olah- 
ragawan (berotot, sehat, kuat, dalam pembentukan, bentuk tubuh bagus); (4) wanita sexy (tubuh bagus, rambut panjang, berpakaian dengan baik, kulit halus, wajah cantik) dan pria macho (berotot, tubuh tinggi berbulu, berkumis, menarik, berpusat pada diri-sendiri); (5) wanita pengusaha (cerdas, pakaian bagus, tidak menikah, pekerjaan berat, teratur) dan pria pengusaha (memakai jas, kantor dengan pandangan bagus, pendidikan perguruan tinggi, cerdas, penampilan bagus).

Temuan penelitian menunjukkan adanya peran media televisi dalam mengukuhkan stereotipisasi peran gender wanita dalam bentuk peran sosial sebagai ibu rumah tangga, posisi sosial sebagai pendamping pria dan sifat personal emosional, pasif, pengalah dan penghindar konflik. Stereotipisasi peran gender semacam ini makin mengukuhkan konstruksi peran gender yang menyudutkan wanita. Mengapa stereotipisasi peran gender tersebut cenderung merugikan kaum wanita? Hal ini terkait dengan latar belakang terjadinya stereotipisasi tersebut yang tidak bisa dilepaskan dari adanya kebencian tertentu oleh kaum pria terhadap kaum wanita.

\section{Misoginisme dan Mitologi Peran Gender Wanita}

Istilah misogini (mysogyny) secara etimologis berasal dari kata misogynia (Yunani) yaitu miso (benci) dan gyne (wanita) yang berarti a hatred of women. Misoginisme (mysogynism) adalah ideologi yang membenci wanita (Gove, 1966).

Feminis psikoanalisis menggunakan istilah misogini (misogyny) untuk menjelaskan adanya kebencian terhadap wanita (hatred of women) yang berakar pada kemarahan bayi primitif terhadap ibunya karena masyarakat memberikan tugas pengasuhan anak kepada wanita (Chodorow, 1989; Humm, 1989).

Faktor apa yang menyebabkan munculnya kebencian terhadap seorang wanita tersebut? Dalam pandangan Umar (1999: 132-133), adanya mitos tentang penciptaan wanita dan keluarnya Adam dari surga ke bumi menjadi sebab munculnya banyak perlakuan kasar dan negatif terhadap wanita. Dalamcerita itu wanita diciptakan untuk melengkapi hasrat Adam dan Adam jatuh ke bumi karena godaan Hawa. Cerita seperti ini melahirkan faham misoginis (pembencian wanita oleh priai). Faham yang berasal dari ajaran YahudiKristen ini berpengaruh cukup luas di dalam dunia Arab melalui berbagai media, seperti kitab-kitab tafsir dan kitab-kitab fiqh.

Keberadaan mitos sebagai akar kebencian terhadap kaum wanita juga bisa dilihat dari penjelasan Hyde (1985). Menurut Hyde, dalam diri kaum wanita dilekatkan mitos-mitos yang kurang menguntungkan bagi mereka, antara lain mitos mengenai kejahatan feminin (feminine evil) yang berasal dari tradisi Judeo-Kristen mengenai kejatuhan manusia dari surga karena kesalahan Eva membujuk Adam untuk makan buah dari pohon pengetahuan. Perbuatan ini dianggap sebagai akar dari dosa asal seluruh umat manusia yang disebabkan oleh perbuatan Eva (wanita). Di Yunani dikenal mitos mengenai Pandora, manusia wanita pertama di dunia, yang membuka kotak terlarang sehingga menyebarlah semua benih kejahatan di atas muka bumi ini. DiCina dikenal dua kekuatan Yin dan Yang yang berhubungan dengan aspek feminin dan maskulin. Yin yang feminin terkait dengan kegelapan, kejahatan, sisi dari alam. Sedang Yang yang maskulin kebalikan dari sifat-sifat tersebut.

Mengapa mitos semacam itu dilekatkan pada diri wanita? Menurut Hyde, pria melihat wanita sebagai pihak yang inferior dan mengekspresikannya melalui bermacam mitos tersebut untuk membuat posisi wanita tetap rendah. Secara psikologis, sifat-sifat yang dilekatkan pada kaum wanita secara terorganisir tersebut muncul disebabkan adanya tekanan dan kecemasan dalam diri kaum pria terhadap keberadaan kaum wanita yang misterius dan tidak mereka ketahui. Mereka tertekan dan cemas karena wanita berbeda dengan mereka. Sebagai pemegang kekuasaan dalam banyak masyarakat dunia, kaum pria mempunyai otoritas atas semua pengetahuan masyarakatnya, termasuk dalam hal menciptakan mitos-mitos yang merendahkan posisi kaum wanita tersebut.

Kekuatan mitos ini demikian hebat karena ia bekerja melalui mekanisme ketidaksadaran (unconscious) manusia. Menurut Carl Jung (dalam Hyde, 1985: 22), ketidaksadaran ini mempunyai 
peran penting dalam pembentukan keseluruhan personalitas manusia. Menurut teori ini, personalitas individual mempunyai akarnya dalam sejarah. Bagian dari mental yang berisi pelacakan memori kuno ini disebut sebagai ketidaksadaran kolektif (collective unconscious). Ketidaksadaran kolektif ini merupakan sebuah gudang memori yang berasal dari generasi-generasi sebelumnya. Oleh Jung, memori semacam itu disebut sebagai memori "rasial". Memori semacam ini merupakan kecenderungan universal yang ada dalam diri setiap manusia untuk berfikir dan merasa dengan suatu cara tertentu. Ketidaksadaran kolektif ini berisi simbol-simbol dan interpretasi-interpretasi universal yang dihayati oleh semua orang, baik orangorang jaman dahulu maupun orang-orang modern sekarang ini. Simbol-simbol tersebut muncul dalam bentuk mimpi dan mitos-mitos. Ketidaksadaran kolektif ini berisi sejumlah pola dasar yang secara universal "ditanamkan" dalam gagasan-gagasan yang berisi sejumlah besar komponen emosional. Misalnya, sebuah pola dasar mengenai konsep ibu (mother) mengacu pada bagaimana citra ibu ini terbentuk selama berabad-abad melalui interaksi manusia dengan ibu. Seorang anak berinteraksi dengan ibunya bukan hanya berdasarkan apa yang dilakukan oleh ibunya, tapi juga berdasarkan pola dasar yang dimiliki oleh anak ini mengenai konsep ibu, yang dimiliki sejak kelahirannya dan dihayatinya bersama-sama dengan orang-orang yang lain.

Dengan mengikuti Jung ini, menurut Hyde, seseorang harus melihat sejarah dan mitologi untuk bisa membuat pemahaman yang lebih baik pada sikap-sikap wanita modern sekarang ini. Sikapsikap terkini itu tidak hanya mungkin hasil interaksi dengan wanita dalam struktur sosial terkini, tapi juga mungkin berisi komponen yang dibawa dari generasi-generasi sebelumnya dalam ketidaksadaran kolektif.

Selaras dengan Jung, Sandra dan Daryl Bem (dalam Hyde, 1985: 38) memperkenalkan konsep ideologi tanpa kesadaran (nonconsciousnes ideology) yang diartikan sebagai sebuah ideologi (serangkaian gagasan) yang kita terima tanpa kesadaran disebabkan: (1) gagasan itu demikian umumnya dan secara luas diterima tanpa dapat dikenali, bagaikan ikan yang tidak sadar bahwa ia hidup di air; dan (2) gagasan itu dalam bentuk yang halus dan tidak bisa diketahui atau diserang. Mitologidan agama merupakan ideologi tanpa kesadaran ini. Bentuk lain adalah leluconlelucon yang menggambarkan wanita sebagai sosok bodoh, dungu, atau tidak berkompeten. Sebuah pandangan yang dipenuhi dengan potensi kebencian tertentu.

\section{Naturalisasi sebagai Mekanisme Sosialisasi}

Dengan mengacu pada konsep ketidaksadaran kolektif ataupun ideologi tanpa kesadaran itu, agaknya adanya kecemasan, ketakutan, ataupun kebencian terhadap kaum wanita tersebut akhirnya menjadi suatu bentuk ketidaksadaran stereotipi tertentu di benak kaum pria sebagai sebuah kelompok sosial dalam memandang kaum wa-nita sebagai kelompok sosial lainnya dalam relasi gender diantara dua kelompok ini di masyarakat. Dalam konteks semacam ini, menurut (Shoemaker dan Reese, 1991), media mempunyai peran strategis dalam nenaturalisasikan ideologi ketidaksadaran tersebut.

Implikasi peran ideologis semacam itu menjadikan sekarang ini sulit untuk mengenali adanya prasangka misoginistik tersebut karena ia sudah mewajar (natural) dalam kehidupan seharihari. Kita menerima stereotipisasi peran gender wanita dalam bentuk peran sosial sebagai ibu rumah tangga, posisi sosial sebagai pendamping pria dan pengasuh anak, serta sifat personal sebagai wanita emosional, pengalah, dan pasif sebagaimana muncul dalam tayangan televisi sebagai sesuatu yang benar dan alamiah.

Menurut Chen (1996: 35), surat kabar, radio, dan komputer adalah milik orang-orang dewasa. Sedang televisi adalah medium anakanak. Bagi anak-anak, televisi adalah "orang asing" dalam rumah yang mengajari anak-anak banyak hal. Hasil riset di Amerika menunjukkan, anakanak menonton televisi rata-rata 4 jam sehari, 28 jam seminggu, 1.400 jam setahun, atau mendekati 18.000 jam sampai seorang anak lulus sekolah menengah atas. Anak-anak meluangkan lebih banyak waktu untuk menonton televisi daripada untuk kegiatan apapun lainnya, kecuali tidur (miring asli dari penulis). Di Indonesia 
sebagaimana ditunjukkan Guntarto (2004), anakanak menghabiskan 35 jam seminggu untuk menonton televisi.

Peran strategis-ideologis media televisi tersebut ditunjukkan oleh Croteau dan Hoynes (2004: 14-15) melalui fungsi sosialisasi dan relasi sosial media massa. Menurut mereka, sosialisasi adalah proses kita belajar dan menginternalisasikan nilai-nilai, keyakinan-keyakinan dan normanorma budaya kita untuk kita gunakan sebagai pembentuk konsep diri kita (self). Sedang relasi sosial terkait dengan kemampuan media tidak sekedar memberi informasi saja tapi juga menunjukkan bagaimana kita menjalin relasi dengan dunia kita: relasi antar individu; relasi individu dengan institusi; relasi individu dalam institusi dan relasi antar institusi.

Artinya semua stereotipe peran gender yang ditayangkan melalui media televisi akan diterima oleh anak-anak yang menonton sebagai tuntunan peran sosial alamiah yang tepat bagi mereka dalam relasi mereka dengan sesamanya maupun relasi mereka dengan berbagai institusi sosial yang ada. Dengan menginternalisasikan nilai-nilai stereotip tersebut, anak-anak akan diterima sebagai warga masyarakat yang normal dan alamiah.

\section{Industri Televisi sebagai Muara Ideologi Gender Dominan}

Struktur ekonomi-politik industri televisi di Indonesia berkembang dalam relasi ekonomi-politik yang ditandai oleh menguat dan melemahnya peran negara (state regulation) dalam mengontrol industri televisi beriringan dengan melemah dan menguatnya peran pasar (market regulation). Sampai dengan akhir tahun 1990-an pendulum kontrol negara atas kehidupan industri televisi berayun pada posisi dominan. Paska gerakan reformasi di akhir tahun 1990-an, pendulum kontrol itu berayun pada posisi lemah digantikan oleh kuatnya peran pasar. Paska tahun 2002, dinamika ekonomi-politik industri televisi didominasi oleh konsolidasi daya-daya yang digerakkan oleh kekuatan mekanisme pasar (market atau moneybased powers) bersama-sama dengan daya-daya politis kekuasaan perangkat negara (state-based powers). Artinya terjadi konsolidasi antara kekuatan negara dengan kekuatan pasar (Sudibyo dalam Sunarto, 2007: 328)

Konsolidasi itu terjadi ketika menguatnya kontrol negara melalui aparatus Departemen Komunikasi dan Informatika terhadap dunia penyiaran didukung oleh para pelaku industrinya. Uji material melalui Mahkamah Konstitusi terhadap beberapa pasal dalam UU Penyiaran dan penerimaan kalangan industri televisi terhadap paket PP Penyiaran mengisyaratkan terjadinya konsolidasi kekuatan negara dan pasar untuk meminggirkan fungsi kontrol masyarakat melalui lembaga KPI.

Selama era Orde Lama kehidupan industri televisi belum berkembang karena keberadaan televisi pada saat itu masih didominasi oleh siaran monolitik TVRI yang menjadi salah satu instrumen penting pemerintah untuk konsolidasi kepentingan politik nasional. Selama Orde Baru berkuasa kedudukan TVRI sebagai instrumen politik penguasa semakin kental. Terlebih dengan diluncurkannya satelit Palapa. Arti penting televisi sebagai instrumen politik semakin menonjol selama era Orde Baru ini.

Komersialisasi industri televisi mulai berlangsung pada akhir tahun 1980-an ketika pemerintah memberi ijin bagi beroperasinya beberapa stasiun televisi swasta. Sampai pertengahan tahun 1990-an industri televisi berkembang tanpa aturan jelas. Aturan di seputar industri televisi hadir tahun 1997 melalui Undang-undang Nomor 24 tentang Penyiaran yang sangat sentralistis. Peraturan ini kemudian direvisi melalui Undangundang Nomor 32 tahun 2002 yang lebih bersifat demokratis dan desentralistis. Aspek demokratisasi industri penyiaran tampak dari diikutsertakannya masyarakat dalam pengelolaan industri televisi melalui lembaga negara independen bernama Komisi Penyiaran Indonesia. Aspek desentralistik tampak dari adanya peluang untuk mendirikan lembaga penyiaran lokal di berbagai daerah.

Praktek dalam industri televisi sendiri masih didomoinasi oleh ideologi kapitalisme dan patriarkisme. Ideologi kapitalisme beroperasi melalui mekanisme komodifikasi isi, khalayak, sibernetika (instrinsik dan ekstensif), dan tenaga kerja (Mosco, 1996) untuk mendulang pendapatan 
dari sirkulasi, iklan, sponsorship dan lain-lain yang relevan dengan bisnis media.

Rating menjadi instrumen penting untuk mengukur sampai sejauhmana isi siaran mampu memenuhi kaidah komodifikasi tersebut. Dibanding media yang lain, media televisi relatif lebih akomodatif dengan kepentingan pemiliknya untuk mendapatkan pemasukan finansial melalui perolehan iklan. Sejak awal tahun 1990-an hingga tahun 2005, belanja iklan televisi relatif lebih tinggi dibanding belanja iklan media lain. Pangsa pasar media untuk belanja iklan semenjak muncul media televisi komersial secara gradual didominasi oleh media baru ini. Dari tahun 1986 hingga 1991, pangsa pasar media untuk belanja iklanitu masih dikuasai media cetak, khususnya surat kabar. Akan tetapi mulai tahun 1992, secara perlahan-lahan media televisi mulai menguasai belanja iklan media Indonesia. Pada tahun 2005 belanja iklan media diproyeksikan benar-benar dikuasai oleh media televisi $(60,4$ persen). Belanja iklan media suratkabar hanya sebanyak 30,1 persen saja. Sisanya diperebutkan antara media radio, majalah, dan luar ruang. Khusus terkait dengan belanja iklan media televisi, selama tahun 2000 - 2004 tampaknya terjadi kompetisi ketat antara stasiun RCTI, Indosiar, SCTV, dan TransTV. Laporan Nielsen Media Research menunjukkan, selama periode Januari - Desember 2005, total belanja semua media (TV, koran, majalah) sebesar Rp 25,8 trilyun dengan belanja iklan televisi mencapai sebanyak Rp 17,7 trilyun (53 persen). Pada periode Januari - September 2006, total belanja semua media mencapai Rp 22,2 trilyun (naik 15 persen dalam periode sama di tahun 2005). Porsi belanja iklan televisi masih lebih besar dibanding media yang lain. Stasiun RCTI masih memimpin pasar dengan perolehan iklan paling besar disusul SCTV dan TransTV (CASBA, 2007: 5-6).

Ideologi patriarkisme beroperasi melalui dominasi pekerja pria dalam struktur organisasi industri televisi (Sunarto, 2007). Secara kuantitatif, jumlah pekerja pria lebih banyak dijumpai dibanding pekerja wanita. Secara manajerial, pekerja pria lebih banyak menduduki jabatan pimpinan dibanding pekerja wanita. Dalam operasionalisasi sehari-hari semua pekerja di stasiun televisi diasumsikan berjenis kelamin pria yang harus selalu siap untuk bertugas kapan saja dan dimana saja. Dalam kompetisi untuk menduduki jabatan tertentu pekerja wanita diperlakukan sama dengan pekerja pria. Ukuran keberhasilan menduduki jabatan ditentukan oleh prestasi kerja bukan perlakuan khusus berdasarkan jenis kelamin. Meskipun secara normatif keberadaan pekerja wanita dilindungi dari pelecehan seksual pekerja pria, dalam realitanya ternyata dijumpai adanya pekerja wanita yang mengalami perlakuan kasar secara verbal. Akan tetapi laporan resmi adanya perlakuan semacam ini pada pihak manajemen tidak pernah dijumpai.

Iklim organisasi yang berkembang dalam industri televisi didominasi oleh nilai-nilai yang bersifat maskulin sehingga mengukuhkan keberadaan industri media televisi sebagai situs pria (male site). Dalam situasi semacam ini, keberadaan pekerja wanita lebih banyak melakukan aktivitas yang mengarah pada reproduksi nilainilai dominan (patriarkistik dan kapitalistik) dibanding melakukan resistensi melalui produksi nilai-nilai alternatif. Meskipun demikian, upaya untuk melakukan resistensi terhadap nilai-nilai dominan itu bukannya tidak ada sama sekali.

Dengan relasi gender yang didominasi pekerja pria ini, sulit bagi pekerja wanita untuk memberdayakan struktur gender mereka untuk melawan dominasi nilai-nilai patriarkistik di lingkungan kerja mereka. Dalam lingkungan kerja yang belum digenderkan ini munculnya tayangan anak-anak berisi kekerasan tertentu terhadap wanita merupakan sebuah implikasi tidak terelakkan karena semuanya masih dianggap wajar dan alamiah oleh segenap pekerja yang ada.

\section{Simpulan}

Dari uraian di atas bisa disimpulkan beberapa hal. Pertama, dalam teks program anakanak produksi lokal dijumpai adanya kekerasan personal dan struktural tertentu terhadap tokoh wanita. Kekerasan personal berupa kekerasan fisik dan psikologis. Kekerasan struktural berupa dominasi tokoh pria atas tokoh wanita dan stereotipesasi peran gender.

Kedua, kekerasan struktural dalam wujud stereotipisasi peran gender wanita terjadi dalam bentuk peran sosial sebagai ibu rumah tangga, posisi sosial sebagai pendamping pria dan penga- 
suh anak dengan atribut personal emosional, pasif, dan penghindar konflik.

Ketiga, latar belakang terjadinya stereotipesasi peran gender wanita adalah adanya kebencian tertentu terhadap keberadaan kaum wanita yang disebarluaskan melalui berbagai mitologi misoginistik yang bekerja melalui ketidaksadaran kolektif atau ideologi tanpa kesadaran. Ideologi gender dominan yang berlaku dalam industri televisi berupa ideologi kapitalisme dan patriarkisme telah menjadikan sterotipesasitersebut wajar dan alamiah.

Disarankan, dalam kadar tertentu stereotipisasi peran gender tetap diperlukan sejauh tidak menyudutkan posisi kaum wanita di masyarakat. Dalam program anak-anak produksi lokal hendaknya dimunculkan beragam peran sosial, posisi sosial dan atribut personal yang tidak merugikan kaum wanita. Tugas para sineas Indonesia untuk menghasilkan karya yang bebas dari bias gender.

\section{Ucapan Terima Kasih}

Penulis menyampaikan penghargaan dan ucapan terima kasih kepada Dirjen Dikti Diknas RI yang telah memungkinkan dilakukannya penelitian berjudul "Strukturasi Gender: Kekerasan terhadap Wanita dalamProgram Televisi Anak di Indonesia" melalui skema Penelitian Fundamental tahun 2009 yang menjadi dasar bagi penulisan artikel ini.

\section{Daftar Pustaka}

Bemmelen, Sita van, 1992, "Media Massa dan Perubahan Nilai Jender", Dalam Lugina Setyawati dan Anastasia Endang (eds.), Media Massa dan Wanita, Fisip UI dan UNIFEM, Jakarta.

CASBAA, 2007, Indonesia in View: A CASBAA market report on the pay-TV Industry in the Republic of Indonesia, Clarity Research Indonesia, Jakarta.

Chen, Milton, 1996, Anak-anak dan Televisi, Gramedia Pustaka Utama, Jakarta.

Chodorow, Nancy, 1989, Feminism and Psychoanalytic Theory, Yale University Press: New Haven.
Croteau, David and William Hoynes, 2000, Media/Society: Industries, Images, and $\mathrm{Au}$ diences (2nd ed.), Pine Forge Press, Thousand Oaks.

Eln, 2010, "Kekerasan Meningkat: Korban Cenderung Berusia Muda", Kompas (8 Maret).

Fairclough, Norman, 1995, Media Discourse, Edward Arnold, London.

Gerbner, George, 2003, "Television Violence: At a Time of Turnmoil and Terror". Dalam Gail Dines and Jean M. Humez (eds.), Gender, Race, and Class in Media:A TextReader (2nd ed.), Sage Publications, London.

Giddens, Anthony, 1986a, The Constitution of Society: Outline of the Theory of Structuration, University of California Press: Berkeley.

Giddens, Anthony, 1986b, Central Problems in Social Research: Action, Structure and Contradiction in Social Analysis. University of California Press, Berkeley dan Los Angeles.

Giddens, Anthony, 1992, Sociology, Polity Press, Great Britaint.

Golding, Peter dan Graham Murdock, 1995, "For a political economy of mass communications", Dalam Oliver Boyd-Barret dan Chris Newbold (eds.), Approaches to Media: A Reader, Edward Arnold, London.

Golding, Peter dan Graham Murdock, 1991, "Culture, Communications, and Political Economy", Dalam James Curran dan Michael Gurevitch (eds.), Mass Media and Society, Edward Arnold, London.

Gove, Philip Babcock, 1966, Webster's Third New International Dictionary of the English Language Unbridged, G. \& C. Merriam Company, Springfield.

Guba, Egon G. dan Yvonna S. Lincoln, 1994, "Competing Paradigms in Qualitative Research", dalam Norman K. Denzin dan Yvonna S. Lincoln, (Eds.), Handbook of Qualitative Research, Sage Publications, London.

Guntarto,B., 2004, "Masukan Untuk Draf Pedoman Perilaku Penyiaran dan Standar 
Program Siaran", Dalam B. Guntarto (Ed.), Mengkritisi Standar Tayangan Anak Dan Remaja, Jakarta.

Guntarto, B., 2000, “An Assessment of Children's Television Programmes in Indonesia", Dalam Anura Goonasekera dan kawankawan (eds.), Growing Up with TV: Asian Children's Experience, AMIC, Singapore.

Gupta, Arun K. dan Nisha Jain, 1989, “Gender, Mass Media and Social Change, A Case Study of TV Commercials", dalam Media Asia, An Asian Mass Communication Quarterly, Singapore.

Humm, Magie, 1989, The Dictionary of Feminist Theory (2nd. Ed.), Ohio State University Press, Columbus.

Hyde, Janet Shibley, 1985, Half The Human Experience: The Psychology of Women (3rd ed.), D.C. Heath and Company, Lexington.

Ibrahim, Idi Subandy dan Hanif Suranto, 1998, Wanita dan Media: Konstruksi Ideologi Gender dalam Ruang Publik Orde Baru, Remaja Rosdakarya, Bandung.

Idrus, Nurul Ilmi, 2004, "Pornografi dalam Pemberitaan", Jurnal Perempuan, Jakarta.

Komnas Perempuan, 2002, Peta Kekerasan: Pengalaman Perempuan Indonesia, Ameepro, Jakarta.

Lok, 2002, "Tingkat Kekerasan terhadap Perempuan Masih Tinggi”, Kompas, Jakarta.

Mosco, Vincent, 1996, The Political Economy of Communication: Rethinking and Renewal, London: Sage Publications.

Neuman, W. Lawrence, 1997, Social Research Methods: Qualitative and Quantitative Approach (3rd ed.), Boston: Allyn and Bacon.

Ribka, Pangemanan Diana, 1998, “Tindak Kekerasan terhadap Perempuan dalam Keluarga”, Tesis, Universitas Indonesia, Jakarta.

Richmond-Abbott, Marie, 1992, Masculine \& Feminine: Gender Roles Over The Life Cycles (2nd ed.), McGraw-Hill, Ind, New York.
Sendjaja, Sasa Djuarsa dan kawan-kawan, 2003, "Reaktualisasi Cerita Anak-anak: Eliminasi Kekerasan terhadap Perempuan dalam Media Anak-anak Indonesia", Laporan Penelitian, Universitas Indonesia, Jakarta.

Shoemaker, Pamela J. dan Stephen D. Reese, 1991, Mediating the Message: Theories of Influence on Mass Media Content, Longman Publishing Group, New York.

Soemandoyo, Priyo, 1999, Wacana Gender dan Layar Televisi: Studi Perempuan dalam Pemberitaan Televisi Swasta, Ford Foundation dan LP3Y, Yogyakarta.

Soetrisno, Ade Latifa, 1999, "Kekerasan Suami terhadap Istri: Sebuah Analisa berperspektif Feminis atas Kasus-kasus di Sebuah Lembaga Konsultasi Perkawinan di Jakarta”, Tesis, Universitas Indonesia, Jakarta.

Sunarto, 2000, Analisis Wacana: Ideologi Gender Media Anak-anak. Semarang: Mimbar bekerjasama dengan yayasan Adikarya Ikapi dan Ford Foundation.

Sunarto, 2007, "Kekerasan Televisi terhadap Wanita: Studi Strukturasi Gender Industri Televisi dalam Naturalisasi Kekerasan terhadap Wanita melalui Program Televisi untuk Anak-anak di Indonesia", Disertasi, Universitas Indonesia, Jakarta.

Susan, Siew dan Wang Lay Kim, 1996, "Do New Communication Technologies Improve The Status of Women? ", dalam Media Asia, An Asian Mass Communication Quarterly, Singapore.

Steeves, H. Leslie, 1993, "Gender and Mass Communication in a Global Context", dalam Pamela J. Creedon, (Ed.), Women in Mass Communication, (Second Edition), Newbury Park, Sage Publications, California.

Umar, Nasaruddin, 1999, Argumen Kesetaraan Jender: Perspektif Al-Qur'an, Paramadina, Jakarta.

Unger, Rhoda dan Mary Crawford, 1992, Women and Gender: A Feminist Psychology, McGraw Hill, United States of America.

Wolffensperger, Joan, 1991, "Engendered Structure: Giddens and the Conceptualization of 
Gender", Dalam Kathy Davis dan kawankawan (eds.), The Gender of Power, Sage Publications, London.

Wolf, Naomi, 1997, Gegar Gender: Kekuasaan Perempuan Menjelang Abad 21, Pustaka Semesta Press, Yogyakarta. 